\title{
Students' Attitudes towards Cultural Learning in the English Classroom: A Case Study of Non-English Major Students in a Chinese University
}

\author{
Songmei Liu (Corresponding author) \\ M.A. Student, Department of Languages and Linguistics, Faculty of Liberal Arts \\ Prince of Songkla University, Hat Yai Campus, Songkhla, Thailand \\ E-mail: songsong1773@sina.cn
}

Chonlada Laohawiriyanon

Asst. Prof. Dr., Department of Languages and Linguistics, Faculty of Liberal Arts, Prince of Songkla University, Hat Yai Campus, Songkhla, Thailand E-mail: chonlada.1@psu.ac.th

Received: November 24, 2014 Accepted: December 25, $2014 \quad$ Published: December 31, 2014

doi:10.5296/jsel.v2i2.6845 URL: http://dx.doi.org/10.5296/jsel.v2i2.6845

\begin{abstract}
The aim of this paper was to investigate Chinese non-English major university students' interest in learning about Big " $\mathrm{C}$ " and little "c" cultural themes of different countries. A questionnaire was randomly distributed to 69 students in a university in China. Research findings revealed that the respondents were in favor of learning mostly about their own culture, followed by target and international target culture. Regarding cultural themes, they seemed to show a slightly stronger preference towards Big "C" over little "c" culture. With respect to Chinese (source) culture, students were interested in learning about "History", "Food", and "Holidays"; for international target culture (i.e. the cultures of France, Egypt, Japan, Brazil, and Iran), the respondents were curious to learn about the cultural themes of "Geography", "Food", and "Holidays"; and for the target culture (i.e. America and Australia), the cultural themes of Science" and "Geography" were favored by the respondents. Pedagogical implications of training learners to improve their ICC are offered.
\end{abstract}

Keywords: Big "C" culture, little "c" culture, sources of culture, Intercultural Communicative Competence (ICC) 


\section{Introduction}

It is trite to say that language and culture are closely linked and culture plays a key role in English Language teaching (ELT). With the advent of English as an international language (EIL), intercultural language learning has become central to modern language education, thus pressing English language teachers to prepare their students for intercultural communication in an increasingly multicultural world. Conceived by the awareness of the inseparability of language and culture, Intercultural Commutative Competence (ICC), the ability to function effectively in intercultural settings, has been widely recognized as the ultimate goal of ELT (Brown, 2000; Byrnes, 2010; Kramsch, 1993; Byram, 1997). Paige et al. (1999) pointed out language and cultural achievements are influenced by many variables such as learners' attitudes, teacher, and learning settings. The significant role of attitude in second language learning is resonated in many studies (Dörnyei, 1994, 2001; Ellis, 1985; Gardner \& Lambert, 1972; Savignon, 1983) in that ESL/EFL language learners are required to have positive attitudes in order to successful in language learning. Moreover, it is important for teachers to know students' attitudes to learning about culture in order to design the ELT curriculum effectively Chlopek (2008).

Taking together the importance of cultural knowledge and attitudes in language learning, the researcher attempted to carry out a survey to identify students' preference of learning both Big "C" and little "c" culture, referred to as cultural themes, from different countries, known as cultural sources. It is expected that the research findings would provide valuable insights into current ELT from the standpoint of what cultural content should be imparted in order to promote Chinese students' language and culture learning as well as ICC.

\section{Literature Review}

\subsection{Culture, Language and ELT}

To define culture is a challenging task. Brown (2000: 177) defines culture as "the ideas, customs, skills, arts and tools that characterize a given group of people in a given period of time". Information, thoughts and feelings are conveyed by language in a language community or culture (Brown, 2000). Fantini (1995) pointed out the interdependent relationship between language and culture since language affects and reflects culture and vice-versa. Echoing Fantini, Brown stated that language and culture are closely connected and inseparable. Language is regarded as a means by which people communicate and interact with others, which in turn is responsible for cultural development.

Due to the inseparable relationship between language and culture, there has been an increase in the number of language educators who emphasize the significant role of culture in the ELT classroom. For instance, McKay (2002) noted that the integration of cultural components into language teaching can increase motivation in a language class. Nault (2006) invited scholars, language educators and practitioners to reconsider the existing condition of cultures and their representation for the development of EIL. He pointed out that English educators should also pay attention to other target cultures besides British and American. Additionally, ELT specialists should select and design the curriculum using international source materials. 


\subsection{Sources of Culture}

As regards culture-related teaching material and textbooks in English classroom, Cortazzi and Jin (1999) offered a new look at the sources of cultural information. They classify the sources of cultural information into source culture (learner's own culture), target culture (any English-speaking countries where English is spoken as a first language), and international target culture (English-speaking or non-speaking English countries around the world where English is not used as a first language).

The reason for introducing source cultural content in ELT textbooks is to cultivate learners' knowledge of their own culture. Students can learn about topics and vocabularies which are related to their native background in English so that they can interact with people from different cultural backgrounds (McKay, 2000).

Target culture knowledge has long been a main component in the ELT classroom because it enhances student motivation toward learning languages (McKay, 2002). The author's consideration of using target culture in the classroom makes it possible for users from different societies to make optimal use of the same materials in both EFL and ESL contexts. Also, since it is difficult for native English speaking ELT textbook writers to source cultural data other than from their own culture, they should look to the target culture for that information (Alptekin, 1993).

However, due to the current shift from ESL/EFL to EIL, cultures other than the target ones should receive equal attention in ELT textbooks (Cortazzi \& Jin, 1999). McKay (2000) stated that there are three benefits of using international target culture in teaching materials. Firstly, it would allow non-native speakers to use sense of what is appropriate in communicating inter-personally. Secondly, it could demonstrate how non-native speakers can effectively use English for international communication. Finally, for English to truly be the "lingua franca" of today there must be a choice for non-native English speakers to reflect cultural norms of culture different from those of countries in which English is the native language.

\subsection{Themes of Culture}

Culture can be generally divided into two types: Big "C" culture and little "c" culture (Lee 2009; Peterson, 2004). Lee (2009: 78) refers to Big " $C$ " culture as "the culture which represents a set of facts and statistics relating to the arts, history, geography, business, education, festivals and customs of a target speech society." For Peterson (2004), the culture relating to grand themes, is classified under Big " $\mathrm{C}$ " culture which includes the following themes such as geography, architecture, classical music, literature, political issues, society's norms, legal foundation, core values, history, and cognitive processes.

Regarding little "c" culture, it involves the routine aspects of life together with attitudes and beliefs. Peterson (2004) defines little "c" culture as the culture focusing on common or minor themes. It includes themes such as opinions, viewpoints, preferences or tastes, gestures, body posture, use of space, clothing styles, food, hobbies, popular music, and popular issues, and certain knowledge (trivia, facts). 
Wintergerst and McVeigh (2010) maintained that students possessing both Big "C" and little "c" culture can effectively take part in intercultural settings. While the domain of capital "C" culture (e.g. arts, history, geography, education, business, etc.) is for the highly educated, little "c" cultural knowledge is essential for intercultural communication because it affects ways of thinking, behaving and the use of a language. The socio-cultural values and norms in little "c" culture help members of a particular culture to use well-mannered language within the target society. However, it can also possibly result in, as Lee (2009) put it, "pragmatic failure" when attempting to communicate with other cultural groups. Therefore, if EFL learners know about little "c" culture in the target culture, they will understand better how those in that culture communicate with each other.

Researchers have incorporated the concepts of Big " $\mathrm{C}$ " and little "c" in their studies to investigate students' attitudes towards cultural learning in EFL classroom. Chen (2004), for example, examined Chinese students' attitudes towards cultural themes in EFL classroom. In his study, Chen proposed a cultural framework based on the model conceptualized by Lessard-Clouston (1996). Chen's framework includes seven themes under Big "C" (music, social norms, education, economy, politics, history and geography) and nine themes under little "c" (daily routine, lifestyle, holiday, food, gesture, weather, greeting, customs and values). Based on Paige et al. (1999)'s model of cultural-specific aspect of culture learning, Lee (2009) designed a set of concrete themes for examination of how culture was taught in Korean EFL textbooks. Lee's framework consisted of 22 themes for Big "C" for example arts, agriculture, education, sports, and politics and 26 themes for little "c" such as freedom, materialism, informality, fairness, and competition. Compared to the previous cultural framework of Chen (2004), Lee (2009)'s framework is more comprehensive and detailed to present the material from the intercultural, sociological, ethnographic and sociolinguistic perspectives. However, Lee's framework is too tedious and does not apply to the current investigation very well. Having considered the respective merits and weaknesses of both cultural frameworks above, the researcher used only 17 cultural themes (10 themes for Big "C" and 7 themes for little "c" culture) as the cultural framework of the current study.

\subsection{Attitudes and Language and Cultural Learning}

A student's attitude has frequently been reported to be an essential component of second language learning pedagogy (Gardner \& MacIntyre, 1992, 1993). Gardner and Lambert (1972), Ellis (1985) and Dörnyei $(1994,2001)$ hold that attitude is one of the essential factors shaping the rate, proficiency, and accomplishment of L2 learning. Attitude, being negative and positive, is believed to have a strong impact on students' success in language learning. Furthermore, learners with a positive attitude towards the target culture and its people can learn the target language better than those who do not have such positive attitude (Chamber, 1999; Gardner, 1985).

There is a close relationship between students' attitude and language as well as culture learning. Paige et al (1999) noted that learners' attitudes are believed to be an influential factor on their language and culture learning process. Byram (1997: 34) in his discussion of attitudes towards acquiring cultural knowledge stated that learners' attitude is one important 
element in ICC and it is regarded as pre-condition for successful interaction. He further explained that attitude means "the attitude of curiosity and openness, of readiness to suspend disbelief and judgment with respect to others' meanings, beliefs and behaviors".

Recent research conducted in this area has shed some light on students' attitude towards language and culture learning in EFL classroom. For instance, Sárdi (2002) surveyed Hungarian university students' attitudes towards specific cultural topics (aesthetic sense, sociological sense, pragmatic sense) of three contexts (target culture context, cross-cultural context, and source culture context) in their EFL courses. It was found firstly that the students were more interested in learning English to improve their career prospects. Secondly, they generally expected a high level of cultural content in their English language classroom. Finally, they wanted more exposure to cross cultural issues (e.g. knowing lives of people of different communities). In 2010, Jiang carried out a survey to investigate the Chinese students' opinion as to which countries' culture they preferred to learn in their English classroom. A relatively low percentage of students expressed an interest in learning culture i.e. $32 \%$ of them were interested in British cultures, $17.5 \%$ in American culture and $14 \%$ in Chinese culture. It could be inferred from the low percentage of the students who showed interest in learning about the cultures of India, France, Japan, and Egypt that the Chinese respondents were not highly interested in international culture.

In relation to students' attitudes towards sources and types of culture, Xiao (2010) carried out a survey on the Chinese English-major students and found that they wanted to learn both target and source culture, but did not value international culture as an important element in their EFL class. The study also revealed that the students preferred to learn Big " $\mathrm{C}$ " culture rather than little "c" culture. The Big "C" topics of their interest were literature \& arts, economy, politics and history.

In summary, the review above demonstrated, despite the awareness of the important role of culture, that EFL learners' interest in and perception of learning culture was varied and thus inconclusive. Additional research is needed to explore students' interest in learning about sources and types of culture because the findings regarding students' preferences for learning about specific cultural themes in sources of culture have particular implications for improving materials, teaching methods, and designing the ELT curriculum to foster students' ICC.

\section{Research Methodology}

\subsection{Questionnaire Respondents}

The population of the survey was 881 second year students from five departments in the College of Arts and Sciences, Yunnan Normal University: Computer Science $(\mathrm{N}=120)$, Management Science $(\mathrm{N}=167)$, Horticulture $(\mathrm{N}=136)$, Foreign Language $(\mathrm{N}=288)$ and Engineering $(\mathrm{N}=170)$. Out of five departments, three departments classified as Non-English major subjects were randomly chosen i.e. Computer Science $(n=28)$, Management Science $(n=26)$, and Horticulture $(n=26)$. Only 80 students were randomly selected from these departments. Their ages ranged from 16-18 with a similar pre-university English education background. In other words, they had learnt English for six years starting from the first year 
of their junior middle school, before entering university. At the university, they were required to study the same compulsory English courses over two years. The textbooks they used were a series of New Horizon College English 1-4, Second Edition ${ }^{1}$. For the first year, English Listening and Speaking 1-2 and Reading and Writing 1-2 are taught; and for the second year English, Listening and Speaking 3-4 and Reading and Writing 3-4 are taught. Each course is taught two hours a week. The questionnaire was distributed to the students when they started their fourth semester, meaning that they were studying Reading and Writing 3-4, and Listening and Speaking 3-4.

\subsection{Questionnaire Construction}

The main purpose of the current study was to survey Chinese non-English major students' attitudes towards cultural learning in the English classroom. The questionnaire was composed of two parts. The first part concerned the respondents' background information such as gender and major subject area. The second part required the respondents to rank 17 cultural themes, adapted from Chen's (2004) and Lee (2009)'s concepts of cultural themes under Big "C C" and little "c", of eight different countries that they preferred to learn in English class. The ranks ranged from 1 (highly interested) to 8 (the least interested). Also, the respondents could put 0 if they were not interested in any cultural themes under a certain country. Moreover, they could put 9 or 10 or 11 if they were interested in learning the cultural themes of countries other than selected by the researcher. Blank spaces were given in the list so that they could add the countries of their own choice. The eight countries were selected based on Cortazzi and Jin (1999)'s idea regarding target, international target, and source culture. For target culture, only Australia and America represented the countries in which English is used as the mother tongue, while Egypt, France, Japan, Iran, and Brazil were chosen to represent international target cultures. In the case of Chinese students, Chinese culture is the "source culture".

To ensure the content validity, the questionnaire items were constructed in English and reviewed by three experts in the field. Taken into consideration the expert's feedback, the questionnaire was then modified in order to make the format both respondent and researcher-friendly. Secondly, given that the respondents were Chinese students, the researcher also translated the questionnaire into Chinese and had it checked by three Chinese English teachers to assure translation validity.

The questionnaire was then piloted with fifteen second year Chinese non-English major students. In this pilot process, when students were required to rank each cultural theme in eight different countries according to their preference, some of pilot respondents did not understand the ranking order process because they were not sure whether they could repeat ranking numbers. Based on this feedback, the instructions in final version was modified by clearly stating that " 0 " (not at all interested) could be repeated, but rankings numbers (e.g. 1, $2,3 \ldots$ ) could not be repeated and an example of how to respond to the questionnaire was provided.

\footnotetext{
${ }^{1}$ According to Liu \& Laohawiriyanon (in press 2013), the textbooks were dominated by target cultural content while there was a small percentage of international target culture and source culture. Also, the predominant cultural theme was the little "c" theme of "values" while there was low coverage of common cultural themes (i.e. "food", "holidays", "geography" and "history").
} 
The questionnaire was administrated at the beginning of their English class time and took no more than 25 minutes to complete. Eighty students responded to the questionnaire, but only 69 questionnaires $(86.25 \%)$ were valid.

\subsection{Data Analysis}

For data analysis, weigh scores were used to calculate the ranks in the following manner. In the questionnaire, the researcher provided eight countries representing three sources of culture for the respondents to rank. The respondents added five more countries. Therefore, in total there were 13 countries. Rank number 1 (country most interested) was assigned 13 points, number 2 was assigned 12 points,... number 13 (country least interested) was assigned 1 point, and 0 (not interested at all) was assigned 0 point, respectively. All the assigned weigh scores were then summed up. The highest weigh score was interpreted as the country in which the respondents were most interested. The weigh scores were tabulated in descending order from the most interested to the least (see Appendix 1).

\section{Findings and Discussion}

\subsection{Students' Preference for Sources of Culture}

Table 1 demonstrates the rank of students' preference for learning about the cultures of different countries in the English classroom. In the survey questionnaire, the researcher provided the name of eight countries representing three sources of culture (target, international and source culture) and invited the respondents to add the name of their preferred countries. As a result, five more countries were ranked (U.K., Korea, Burma, Afghanistan, and Pakistan respectively). However, the frequency of those ranked countries was quite low. Therefore, the researcher put those five countries together under a new category "others". This is the reason why the weigh scores of "others" cannot be ranked. (See Appendix 1 for more details).

Table 1. Rank of students' preference for sources of culture in English classroom

\begin{tabular}{|l|l|l|l|l|l|}
\hline Countries & $\begin{array}{l}\text { Target } \\
\text { Culture }\end{array}$ & $\begin{array}{l}\text { International } \\
\text { target culture }\end{array}$ & $\begin{array}{l}\text { Source } \\
\text { culture }\end{array}$ & $\begin{array}{l}\text { Weigh } \\
\text { scores }\end{array}$ & Rank \\
\hline China & & & $\checkmark$ & $\mathbf{1 2 7 7 2}$ & $\mathbf{1}$ \\
\hline America & $\checkmark$ & & & $\mathbf{1 0 8 2 6}$ & 2 \\
\hline France & & $\checkmark$ & & $\mathbf{9 7 9 2}$ & 3 \\
\hline Australia & $\checkmark$ & & & $\mathbf{8 5 6 9}$ & 4 \\
\hline Egypt & & $\checkmark$ & & $\mathbf{7 9 3 8}$ & $\mathbf{5}$ \\
\hline Japan & & $\checkmark$ & & 7729 & 6 \\
\hline Brazil & & $\checkmark$ & & 7029 & 7 \\
\hline Iran & & $\checkmark$ & & 5658 & 8 \\
\hline Others & & & 414 & N/A \\
\hline
\end{tabular}


According to the data in Table 1, it can be seen that the respondents demonstrated their interest in diverse cultural sources. To be more specific, of the top five countries receiving the high degree of interest, it is apparent that the Chinese students showed the highest degree of interest in their native culture. America and Australia, the two countries where English is the mother tongue, were ranked second and fourth. France and Egypt, the two countries where English is used as an international language were third and fifth. In spite of the students' interest in diverse cultural sources, caution should be taken before concluding that the students would function effectively in intercultural interaction. This is because they lacked interest in essential cultural themes of those countries, as shown in Table 2 below.

\subsection{Students' Preference for Themes of Culture}

Table 2 illustrates the rank, ranging from 1-17 according to the number of all cultural themes, and weigh scores of students' preference for cultural themes in their English classroom. It also identifies whether the ranked cultural themes were Big "C" or little "c" culture.

Table 2. Rank of students' preference for cultural themes in English classroom

\begin{tabular}{|l|l|l|l|l|}
\hline Themes & Big C & Little c & Weigh scores & Rank \\
\hline Geography & $\checkmark$ & & 4485 & $\mathbf{1}$ \\
\hline Food & & $\checkmark$ & 4345 & $\mathbf{2}$ \\
\hline Holidays & & $\checkmark$ & 4336 & $\mathbf{3}$ \\
\hline Science & $\checkmark$ & & 4329 & 4 \\
\hline History & $\checkmark$ & & 4295 & $\mathbf{5}$ \\
\hline Social norms & $\checkmark$ & & 4254 & 6 \\
\hline Architecture & $\checkmark$ & & 4249 & 7 \\
\hline Economy & $\checkmark$ & & 4247 & 8 \\
\hline Lifestyles & & $\checkmark$ & 4211 & 9 \\
\hline Customs & & $\checkmark$ & 4193 & 10 \\
\hline Education & $\checkmark$ & & 4155 & 11 \\
\hline Values & & $\checkmark$ & 4122 & 12 \\
\hline Literature/Arts & $\checkmark$ & & 4069 & 13 \\
\hline Body language & & $\checkmark$ & 3908 & 14 \\
\hline Politics & $\checkmark$ & & 3866 & 15 \\
\hline Hobbies & & $\checkmark$ & 3844 & 16 \\
\hline Music/Sports & $\checkmark$ & & 3819 & 17 \\
\hline
\end{tabular}

Overall, it can be seen from Table 2 that the respondents preferred to learn Big " $\mathrm{C}$ " culture to little "c" (10 Big "C" and 7 little "c" themes). This is also apparent when considering only the top five preferred cultural themes (Geography, Food, Holidays, Science, and History). The three most preferred Big "C" themes were "Geography", "Science" and "History", and the 
two most preferred little "c" themes were "Food" and "Holidays" This suggests that respondents seemed to have a slight inclination to learning about Big " $\mathrm{C}$ " cultural themes.

A further analysis was made in order to provide a clearer picture as to which highly preferred cultural themes fell under which highly preferred sources of culture. Table 3 revealed the results of mapping the ranking for preferred cultural themes with their cultural sources.

Table 3. Top five preferred cultural themes and sources

\begin{tabular}{|l|l|l|l|}
\hline Themes & $\begin{array}{l}\text { Target } \\
\text { culture }\end{array}$ & $\begin{array}{l}\text { International } \\
\text { target culture }\end{array}$ & $\begin{array}{l}\text { Source } \\
\text { culture }\end{array}$ \\
\hline Geography $^{*}$ & $\mathbf{5}$ & $\mathbf{1}$ & 7 \\
\hline Food ** $^{*}$ Holidays* & 13 & $\mathbf{3}$ & $\mathbf{2}$ \\
\hline Science* $^{*}$ & 8 & $\mathbf{4}$ & $\mathbf{3}$ \\
\hline History $^{*}$ & $\mathbf{2}$ & 8 & 9 \\
\hline Social norms & 11 & 6 & $\mathbf{1}$ \\
\hline Architecture & 14 & 5 & 8 \\
\hline Economy & 4 & 1 & 12 \\
\hline Lifestyles & 6 & 11 & 4 \\
\hline Customs & 12 & 9 & 10 \\
\hline Education & 1 & 12 & 6 \\
\hline Values & 3 & 13 & 17 \\
\hline Literature/art & 16 & 10 & 16 \\
\hline Body language & 9 & 14 & 5 \\
\hline Politics & 7 & 17 & 15 \\
\hline Hobbies & 10 & 16 & 11 \\
\hline Music/sports & 17 & 15 & 13 \\
\hline
\end{tabular}

Note: * refers to Big " $C$ " cultural theme and ** refers to little " $c$ " cultural theme

Table 3 revealed a more precise and interesting picture about the respondents' interest in culture learning in that their highest interest was learning about their native culture. Three cultural themes in order of preference were "History", "Food", and "Holidays". For international target culture, (i.e. the cultures of France, Egypt, Japan, Brazil, and Iran) the respondents preferred to learn about "Geography", "Food", and "Holidays". Interestingly enough, two little "c" themes ("Food" and "Holidays") were the two common preferred themes of both source and international target culture, but not the target culture. The respondents were curious about "Science" and "Geography" in the target culture (i.e. America and Australia).

Drawing upon the results shown in Tables 1-3, it can be concluded that the respondents preferred to learn about their own culture, followed by target and international target cultures. For cultural themes, they seemed to show a slightly higher interest in Big "C" than in little 
"c" culture. Among the top five preferred cultural themes, there were three common themes i.e. "Food", "Holidays", and "Geography".

According to the findings above, the fact that there was a distribution of interest in learning culture from difference cultural sources, although unequal, may indicate that the respondents can, to a certain extent, acquire ICC due to their positive attitudes towards learning diverse cultures. This view can be supported by Byram (1997: 35) who maintained in his discussion of attitudes towards cultural learning that "...the skills of discovery and interaction are less difficult to operate, less likely to involve psychological stress... if the person involved has attitudes of openness and curiosity". Moreover, the order of the respondents' interest (source culture, target culture, and internal target culture respectively) seems to be appropriate based on Chlopek (2008)'s intercultural approach. According to the approach, priority should be given to the students' own cultural background, followed by the cultures that students have direct contact with. The third priority expands from the first two until all world cultures have been covered.

However, when considering the types of knowledge the students in this study preferred to learn in the EFL classroom, it cannot be assumed that they would be able to communicate successfully in intercultural communities. It was found that the student respondents were inclined to preferred Big " $\mathrm{C}$ " cultural themes as against little "c" ones. This finding is in agreement with the study by Xiao (2010) who found in her study that the English major students had a stronger preference towards Big "C" culture than little "c" culture. Although both Big "C" and little "c" cultural knowledge contributes to a successful communication in intercultural settings (Wintergerst \& McVeigh, 2010), it seems that the knowledge of little "c" culture can prevent misunderstanding and miscommunication among interlocutors from different cultural backgrounds (Lee, 2009). Moreover, the respondents in the current study showed a low interest in the little "c" theme of "Body Language". Reasoned by Wintergerst $\&$ McVeigh (2010), non-verbal communication such as body language, plays an important role of in inter-cultural communication because more than half of a conversation is communicated in ways other than by speaking. Since non-verbal language is a little "c" theme, the students' preference for Big "C" knowledge may inhibit their intercultural communicative ability. This can also be supported by Chastain (1976: 388) that the Big "C" culture "may not contribute significantly to the students' ability to function linguistically and socially in the contemporary culture or to their intercultural understanding."

Another interesting finding is that there is a mismatch between students' interest in cultural learning and the cultural contents of their English textbook used in English class. More specifically, according to the findings above that the students were highly interested in source culture. However, it was found there was fairly low percentage of source culture $(2.2 \%)$ in their English textbooks (Liu \& Laohawiriyanon, 2013 in press). Moreover, the results showed that the top five preferred cultural themes were "Geography", "Food", "Holidays", "Science" and "History in their English classroom. However, information about those cultural themes was virtually absent in their English textbooks (Liu \& Laohawiriyanon, 2013 in press). It can be argued that such treatment of cultural contents in English textbooks might not be sufficient motivation for fulfilling students' need for cultural learning. 


\section{Summary and Implications}

This present study investigated the interest of Chinese non-English major students towards cultural learning in their English classroom. The findings revealed that the respondents were in favor of learning mostly about their own culture, followed by target and international target culture. Regarding cultural themes, they seemed to have a slightly stronger preference towards Big "C" over little "c" culture. With respect to Chinese (source) culture, students were interested in learning about "History", "Food", and "Holidays"; for international target culture (i.e. the cultures of France, Egypt, Japan, Brazil, and Iran), the respondents were curious to learn about the cultural themes of "Geography", "Food", and "Holidays"; and for the target culture (i.e. America and Australia), the cultural themes of Science" and "Geography" were favored by the respondents.

On the basis of the research findings, some teaching implications are evident, mainly for mono-cultural classes. Firstly, in order to promote Chinese students' ICC, especially for those who do not take English as their major subject, English courses as well as textbooks should contain a balanced representation of cultural sources and themes. As well, ELT teachers can look at different ways to motivate students to be curious to explore various cultural themes especially little "c" themes. Studies conclude learning little "c" cultural themes greatly contribute to cultural learning and ICC. However, this study found that the textbooks used by the students had minimal little "c" content. As well, students had minimal interest in little "c" themes such as "Body language". Therefore, the study suggests that EFL teachers should provide supplementary authentic teaching materials about cultural themes from diverse cultural sources in order to motivate students and expose them to more varied cultures. They can also use documentaries, video, or film to illustrate appropriate nonverbal communication in both international and target cultures in order to help students identify the meaning of gestures from different cultures. For students with advanced language skills, presentations and discussions/debates can be used for cultural knowledge learning. For example, students can discuss the similarities and differences between cultures. Finally, role-plays are another activity which can be used for skills and attitudes training to motivate students and to strengthen cultural knowledge learning.

\section{Suggestions for Further Research}

Some of the issues remaining to be investigated include the following. First, further research needs to be drawn from a larger sample size. Second, reasons why students prefer a particular source of culture over another, and a particular cultural theme over another should be investigated. Finally, teachers' perception towards ICC, as well as how to teach culture need further research.

\section{Acknowledgement}

We would like to express deep gratitude to Prof. Yang Tao (Yunnan Normal University), who assisted with data collection and encouraged us to complete this investigation. We also would like to thank to David Bruner and Stefania Vignotto for revising the manuscript. As well, a 
special word of thanks would go to Bai Gengyun, Liu Guangyu, and Huang Yanru for their understanding and supporting.

\section{References}

Alptekin, C. (1993). Target-language culture in ELT materials. ELT Journal, 47(2), 136-143. http://dx.doi.org/ 10.1093/elt/47.2.136

Brown, H. D. (2000). Principles and language learning and teaching ( $4^{\text {th }}$ ed.). White Plains, NY: Addison Wesley Longman.

Byram, M. (1997). Teaching and assessing intercultural communicative competence. Clevedon, UK: Multilingual Matters.

Byrnes, H. (2010). Revisiting the role of culture in the foreign language curriculum. The Modern Language Journal, 335-336. http://dx.doi.org/10.1111/j.1540-4781.2010.01023.x

Chambers, G. N. (1999). Motivating language learners. Clevedon: Multilingual Matters.

Chastain, K. (1976). Developing second-language skill: Theory and practice (2 ${ }^{\text {nd }}$ ed.). Chicago: Rand McNally College.

Chen B. B. (2004). A survey on cultural learning and its variables analysis. Journal of Xi'an International Studies University, 12(3), 21-24.

Chlopek, Z. (2008). The intercultural approach to EFL teaching and learning. English Teaching Forum, 46(4), 10-19.

Cortazzi, M., \& Jin, L.X. (1999). Cultural mirrors: materials and method in the EFL classroom. In Hinkel, E. (ed.), Culture in Second Language Teaching. Cambridge: Cambridge University Press, 196-219.

Dörnyei, Z. (1994). Motivation and motivating in the foreign language classroom. Modern Language Journal, 78(3), 273-284.

Dörnyei, Z. (2001). Motivational strategies in the language classroom. Cambridge: Cambridge University Press.

Ellis, R. (1985). Understanding second language acquisition. Oxford: Oxford University Press.

Fantini, A. (1995). Introduction-language, culture and world view: Exploring the nexus. International Journal of Intercultural Relations, 199(2), 143-153.

Gardner, R. C., \& Lambert, W. E. (1972). Attitudes and motivation in second language learning. Rowley, MA: Newbury House.

Gardner, R. C. (1985). Social psychology and second language learning: The role of attitudes and motivation. London: Edward Arnold. 
Gardner, R. C., \& MacIntyre, P. D. (1992). A student's contribution to second language learning. Part I: Cognitive variables. Language Teaching, 25, 211-220.

Gardner, R. C., \& MacIntyre, P. D. (1993). A student's contribution to second language learning. Part II: Affective variables. Language Teaching, 26, 1-11.

Jiang, B. (2010). The role of College English textbooks in the teaching of culture in China. Unpublished doctor's thesis, University of York Department of Educational Studies.

Kramsch, C. (1993). Context and culture in language teaching. Oxford, UK: Oxford University Press.

Lee, K-Y. (2009). Treating culture: what 11 high school EFL conversation textbooks in South Korea do. English Teaching: practice and Critique, 8(1), 76-96.

Lessard-Clouston, M. (1996). Chinese teachers' view of culture in their EFL learning and teaching. Language, Culture and curriculum, 9(3), 197-224.

Liu, S. M., \& Laohawiriyanon, C. (2013, in press). Cultural Content in EFL Listening and Speaking Textbooks for Chinese University Students. International Journal of English Language Education.

McKay, S. L. (2000). Teaching English as an international language: Implications for cultural materials in the classroom. TESOL Journal, 9(4), 7-11. http://dx.doi.org/10.1002/j.1949-3533.2000.tb00276.x

McKay, S.L. (2002). Teaching English as international language: Rethinking goals and approaches. Oxford: Oxford: Oxford University Press.

Nault, D. (2006). Going global: Rethinking culture teaching in ELT contexts. Language, Culture and Curriculum, 19(3), 314-328.

Paige, M., Jorstad, H., Siaya, L., Klein, F., \& Colby, J. (1999). Culture learning in language education: a review of literature. http://www.carla.umn.edu/culture/resources/litreview.pdf

Peterson, B. (2004). Cultural intelligence: A guide to working with people from other cultures. Yarmouth, ME: Intercultural Press.

Sárdi, C. (2002). On the Relationship between Culture and ELT. Kalbu Studijos, No.3, 101-107.

Savigon, S. J. (1983). Communication competence: Theory and classroom practice. Reading, MA: Addison-Wesley.

Wintergerst, A. C., \& McVeigh, J. (2010). Tips for teaching culture: A practical approach to intercultural communication. White Plains, NY: Pearson Longman.

Xiao, J. (2010). Cultural contents of an in-use EFL textbook and English major students' attitudes and perceptions toward culture learning at Jiangxi University of Science and Technology, China. Unpublished master's thesis, Prince of Songkla University, Songkhla, Thailand. 


\section{Appendix 1}

\begin{tabular}{|c|c|c|c|c|c|c|c|c|c|c|c|c|c|c|c|}
\hline \multirow[b]{2}{*}{ Themes } & \multirow[b]{2}{*}{$\begin{array}{c}\text { Chin } \\
\text { a }\end{array}$} & \multirow[b]{2}{*}{ U.S. } & \multirow[b]{2}{*}{$\begin{array}{c}\text { Fran } \\
\text { ce }\end{array}$} & \multirow[b]{2}{*}{$\begin{array}{c}\text { Austr } \\
\text { alia }\end{array}$} & \multirow[b]{2}{*}{$\begin{array}{c}\text { Egy } \\
\text { pt }\end{array}$} & \multirow[b]{2}{*}{$\begin{array}{c}\text { Japa } \\
\mathbf{n}\end{array}$} & \multirow[b]{2}{*}{$\begin{array}{c}\text { Braz } \\
\text { il }\end{array}$} & \multirow[b]{2}{*}{ Iran } & \multicolumn{5}{|c|}{ Other countries } & \multirow[b]{2}{*}{$\begin{array}{l}\text { Tot } \\
\text { al }\end{array}$} & \multirow[b]{2}{*}{$\begin{array}{l}\text { Ra } \\
\text { nk }\end{array}$} \\
\hline & & & & & & & & & $\begin{array}{l}\text { U. } \\
\text { K. }\end{array}$ & $\begin{array}{l}\text { Ko } \\
\text { rea }\end{array}$ & $\begin{array}{c}\text { Bu } \\
\text { rm } \\
\text { a }\end{array}$ & $\begin{array}{c}\text { Afghani } \\
\text { stan }\end{array}$ & $\begin{array}{l}\text { Paki } \\
\text { stan }\end{array}$ & & \\
\hline $\begin{array}{c}\text { Geograp } \\
\text { hy }\end{array}$ & $\begin{array}{c}788.0 \\
0\end{array}$ & $\begin{array}{c}645.0 \\
0\end{array}$ & $\begin{array}{c}535 . \\
00\end{array}$ & $\begin{array}{c}583.0 \\
0\end{array}$ & $\begin{array}{c}559 . \\
00\end{array}$ & $\begin{array}{c}468 . \\
00\end{array}$ & $\begin{array}{c}489 . \\
00\end{array}$ & $\begin{array}{c}397 . \\
00\end{array}$ & $\begin{array}{l}11 . \\
00\end{array}$ & $\begin{array}{c}0.0 \\
0\end{array}$ & $\begin{array}{l}10 . \\
00\end{array}$ & 0.00 & 0.00 & $\begin{array}{c}448 \\
5.0 \\
0\end{array}$ & 1 \\
\hline Food & $\begin{array}{c}829.0 \\
0\end{array}$ & $\begin{array}{c}601.0 \\
0\end{array}$ & $\begin{array}{c}668 . \\
00\end{array}$ & $\begin{array}{c}466.0 \\
0\end{array}$ & $\begin{array}{c}380 . \\
00\end{array}$ & $\begin{array}{c}557 . \\
00\end{array}$ & $\begin{array}{c}431 . \\
00\end{array}$ & $\begin{array}{c}383 . \\
00\end{array}$ & $\begin{array}{c}9.0 \\
0\end{array}$ & $\begin{array}{l}10 . \\
00\end{array}$ & $\begin{array}{l}11 . \\
00\end{array}$ & 0.00 & 0.00 & $\begin{array}{c}434 \\
5.0 \\
0\end{array}$ & 2 \\
\hline Holidays & $\begin{array}{c}802.0 \\
0\end{array}$ & $\begin{array}{c}593.0 \\
0\end{array}$ & $\begin{array}{c}576 . \\
00\end{array}$ & $\begin{array}{c}518.0 \\
0\end{array}$ & $\begin{array}{c}530 . \\
00\end{array}$ & $\begin{array}{c}473 . \\
00\end{array}$ & $\begin{array}{c}456 . \\
00\end{array}$ & $\begin{array}{c}361 . \\
00\end{array}$ & $\begin{array}{l}11 . \\
00\end{array}$ & $\begin{array}{c}5.0 \\
0\end{array}$ & $\begin{array}{l}11 . \\
00\end{array}$ & 0.00 & 0.00 & $\begin{array}{c}433 \\
6.0 \\
0\end{array}$ & 3 \\
\hline Science & $\begin{array}{c}742.0 \\
0\end{array}$ & $\begin{array}{c}744.0 \\
0\end{array}$ & $\begin{array}{c}551 . \\
00\end{array}$ & $\begin{array}{c}537.0 \\
0\end{array}$ & $\begin{array}{c}418 . \\
00\end{array}$ & $\begin{array}{c}567 . \\
00\end{array}$ & $\begin{array}{c}403 . \\
00\end{array}$ & $\begin{array}{c}367 . \\
00\end{array}$ & $\begin{array}{c}0.0 \\
0\end{array}$ & $\begin{array}{c}0.0 \\
0\end{array}$ & $\begin{array}{c}0.0 \\
0\end{array}$ & 0.00 & 0.00 & $\begin{array}{c}432 \\
9.0 \\
0\end{array}$ & 4 \\
\hline History & $\begin{array}{c}829.0 \\
0\end{array}$ & $\begin{array}{c}608.0 \\
0\end{array}$ & $\begin{array}{c}561 . \\
00\end{array}$ & $\begin{array}{c}475.0 \\
0\end{array}$ & $\begin{array}{c}618 . \\
00\end{array}$ & $\begin{array}{c}452 . \\
00\end{array}$ & $\begin{array}{c}416 . \\
00\end{array}$ & $\begin{array}{c}305 . \\
00\end{array}$ & $\begin{array}{l}12 . \\
00\end{array}$ & $\begin{array}{c}9.0 \\
0\end{array}$ & $\begin{array}{l}10 . \\
00\end{array}$ & 0.00 & 0.00 & $\begin{array}{c}429 \\
5.0 \\
0\end{array}$ & 5 \\
\hline $\begin{array}{l}\text { Social } \\
\text { norms }\end{array}$ & $\begin{array}{c}775.0 \\
0\end{array}$ & $\begin{array}{c}581.0 \\
0\end{array}$ & $\begin{array}{c}666 . \\
00\end{array}$ & $\begin{array}{c}477.0 \\
0\end{array}$ & $\begin{array}{c}501 . \\
00\end{array}$ & $\begin{array}{c}504 . \\
00\end{array}$ & $\begin{array}{c}372 . \\
00\end{array}$ & $\begin{array}{c}346 . \\
00\end{array}$ & $\begin{array}{l}12 . \\
00\end{array}$ & $\begin{array}{c}9.0 \\
0\end{array}$ & $\begin{array}{l}11 . \\
00\end{array}$ & 0.00 & 0.00 & $\begin{array}{c}425 \\
4.0 \\
0\end{array}$ & 6 \\
\hline $\begin{array}{c}\text { Architect } \\
\text { ure }\end{array}$ & $\begin{array}{c}718.0 \\
0\end{array}$ & $\begin{array}{c}591.0 \\
0\end{array}$ & $\begin{array}{c}654 . \\
00\end{array}$ & $\begin{array}{c}471.0 \\
0\end{array}$ & $\begin{array}{c}611 . \\
00\end{array}$ & $\begin{array}{c}444 . \\
00\end{array}$ & $\begin{array}{c}421 . \\
00\end{array}$ & $\begin{array}{c}318 . \\
00\end{array}$ & $\begin{array}{l}10 . \\
00\end{array}$ & $\begin{array}{c}0.0 \\
0\end{array}$ & $\begin{array}{l}11 . \\
00\end{array}$ & 0.00 & 0.00 & $\begin{array}{l}424 \\
9.0\end{array}$ & 7 \\
\hline Economy & $\begin{array}{c}799.0 \\
0\end{array}$ & $\begin{array}{c}729.0 \\
0\end{array}$ & $\begin{array}{c}582 . \\
00\end{array}$ & $\begin{array}{c}504.0 \\
0\end{array}$ & $\begin{array}{c}407 . \\
00\end{array}$ & $\begin{array}{c}521 . \\
00\end{array}$ & $\begin{array}{c}412 . \\
00\end{array}$ & $\begin{array}{c}262 . \\
00\end{array}$ & $\begin{array}{c}9.0 \\
0\end{array}$ & $\begin{array}{c}9.0 \\
0\end{array}$ & $\begin{array}{l}13 . \\
00\end{array}$ & 0.00 & 0.00 & $\begin{array}{c}424 \\
7.0 \\
0\end{array}$ & 8 \\
\hline Lifestyles & $\begin{array}{c}738.0 \\
0\end{array}$ & $\begin{array}{c}665.0 \\
0\end{array}$ & $\begin{array}{c}576 . \\
00\end{array}$ & $\begin{array}{c}523.0 \\
0\end{array}$ & $\begin{array}{c}426 . \\
00\end{array}$ & $\begin{array}{c}524 . \\
00\end{array}$ & $\begin{array}{c}410 . \\
00\end{array}$ & $\begin{array}{c}321 . \\
00\end{array}$ & $\begin{array}{l}12 . \\
00\end{array}$ & $\begin{array}{c}5.0 \\
0\end{array}$ & $\begin{array}{l}11 . \\
00\end{array}$ & 0.00 & 0.00 & $\begin{array}{c}421 \\
1.0 \\
0\end{array}$ & 9 \\
\hline Customs & $\begin{array}{c}789.0 \\
0\end{array}$ & $\begin{array}{c}567.0 \\
0\end{array}$ & $\begin{array}{c}535 . \\
00\end{array}$ & $\begin{array}{c}507.0 \\
0\end{array}$ & $\begin{array}{c}532 . \\
00\end{array}$ & $\begin{array}{c}470 . \\
00\end{array}$ & $\begin{array}{c}412 . \\
00\end{array}$ & $\begin{array}{c}348 . \\
00\end{array}$ & $\begin{array}{l}12 . \\
00\end{array}$ & $\begin{array}{l}10 . \\
00\end{array}$ & $\begin{array}{l}11 . \\
00\end{array}$ & 0.00 & 0.00 & $\begin{array}{c}419 \\
3.0 \\
0\end{array}$ & 10 \\
\hline $\begin{array}{c}\text { Educatio } \\
\text { n }\end{array}$ & $\begin{array}{c}619.0 \\
0\end{array}$ & $\begin{array}{c}761.0 \\
0\end{array}$ & $\begin{array}{c}584 . \\
00\end{array}$ & $\begin{array}{c}570.0 \\
0\end{array}$ & $\begin{array}{c}356 . \\
00\end{array}$ & $\begin{array}{c}474 . \\
00\end{array}$ & $\begin{array}{c}415 . \\
00\end{array}$ & $\begin{array}{c}353 . \\
00\end{array}$ & $\begin{array}{l}11 . \\
00\end{array}$ & $\begin{array}{c}0.0 \\
0\end{array}$ & $\begin{array}{l}12 . \\
00\end{array}$ & 0.00 & 0.00 & $\begin{array}{c}415 \\
5.0 \\
0\end{array}$ & 11 \\
\hline Values & $\begin{array}{c}689.0 \\
0\end{array}$ & $\begin{array}{c}713.0 \\
0\end{array}$ & $\begin{array}{c}596 . \\
00\end{array}$ & $\begin{array}{c}525.0 \\
0\end{array}$ & $\begin{array}{c}418 . \\
00\end{array}$ & $\begin{array}{c}483 . \\
00\end{array}$ & $\begin{array}{c}375 . \\
00\end{array}$ & $\begin{array}{c}307 . \\
00\end{array}$ & $\begin{array}{l}11 . \\
00\end{array}$ & $\begin{array}{c}5.0 \\
0\end{array}$ & $\begin{array}{c}0.0 \\
0\end{array}$ & 0.00 & 0.00 & $\begin{array}{c}412 \\
2.0 \\
0\end{array}$ & 12 \\
\hline Literatur & 796.0 & 565.0 & 575. & 475.0 & 555. & 389. & 393. & 302. & 12. & 7.0 & 0.0 & 0.00 & 0.00 & 406 & 13 \\
\hline
\end{tabular}




\begin{tabular}{|c|c|c|c|c|c|c|c|c|c|c|c|c|c|c|c|}
\hline e/art & 0 & 0 & 00 & 0 & 00 & 00 & 00 & 00 & 00 & 0 & 0 & & & $\begin{array}{c}9.0 \\
0\end{array}$ & \\
\hline Hobbies & $\begin{array}{c}717.0 \\
0\end{array}$ & $\begin{array}{c}617.0 \\
0\end{array}$ & $\begin{array}{c}537 . \\
00\end{array}$ & $\begin{array}{c}481.0 \\
0\end{array}$ & $\begin{array}{c}438 . \\
00\end{array}$ & $\begin{array}{c}372 . \\
00\end{array}$ & $\begin{array}{c}378 . \\
00\end{array}$ & $\begin{array}{c}284 . \\
00\end{array}$ & $\begin{array}{l}12 . \\
00\end{array}$ & $\begin{array}{c}8.0 \\
0\end{array}$ & $\begin{array}{c}0.0 \\
0\end{array}$ & 0.00 & 0.00 & $\begin{array}{c}384 \\
4.0 \\
0\end{array}$ & 16 \\
\hline $\begin{array}{c}\text { Music/sp } \\
\text { orts }\end{array}$ & $\begin{array}{c}715.0 \\
0\end{array}$ & $\begin{array}{c}557.0 \\
0\end{array}$ & $\begin{array}{c}548 . \\
00\end{array}$ & $\begin{array}{c}470.0 \\
0\end{array}$ & $\begin{array}{c}368 . \\
00\end{array}$ & $\begin{array}{c}276 . \\
00\end{array}$ & $\begin{array}{c}497 . \\
00\end{array}$ & $\begin{array}{c}351 . \\
00\end{array}$ & $\begin{array}{l}11 . \\
00\end{array}$ & $\begin{array}{l}13 . \\
00\end{array}$ & $\begin{array}{l}13 . \\
00\end{array}$ & 0.00 & 0.00 & $\begin{array}{r}381 \\
9.0\end{array}$ & 17 \\
\hline Total & $\begin{array}{l}12,77 \\
2.00\end{array}$ & $\begin{array}{c}10,82 \\
6.00\end{array}$ & $\begin{array}{l}9,79 \\
2.00\end{array}$ & $\begin{array}{c}8,569 \\
.00\end{array}$ & $\begin{array}{l}7,93 \\
8.00\end{array}$ & $\begin{array}{l}7,72 \\
9.00\end{array}$ & $\begin{array}{l}7,02 \\
9.00\end{array}$ & $\begin{array}{l}5,65 \\
8.00\end{array}$ & $\begin{array}{r}166 \\
.00\end{array}$ & $\begin{array}{l}90 . \\
00\end{array}$ & $\begin{array}{r}135 \\
.00\end{array}$ & 12.00 & 11.00 & & \\
\hline Rank & 1 & 2 & 3 & 4 & 5 & 6 & 7 & 8 & \multicolumn{7}{|c|}{414.00} \\
\hline
\end{tabular}

\section{Copyright Disclaimer}

Copyright for this article is retained by the author(s), with first publication rights granted to the journal.

This is an open-access article distributed under the terms and conditions of the Creative Commons Attribution license (http://creativecommons.org/licenses/by/3.0/). 